\title{
OBITUARY
}

\section{ARTHUR HUNTER}

\author{
LL.D., F.R.S.E., F.F.A., F.S.A., F.C.A.S., \\ Chevalier of the Legion of Honour (France).
}

When Arthur Hunter died on 27th January 1964 in his 95th year he was the oldest member of the Faculty and also had the distinction which, according to the records, has hitherto been achieved by only one other member, of having been a Fellow for more than 70 years

Hunter was born in Edinburgh in 1869, educated there at George Watson's College, and on leaving school in 1885 joined the service of the Life Association of Scotland. He became a student of the Faculty, completed the examinations in 1892, and was admitted a Fellow in 1893.

In 1892 he went to the U.S.A. to the Fidelity Mutual Life Insurance Co. in Philadelphia and a few years later transferred to the New York Life Insurance Co. where he spent the rest of his career and eventually became senior Vice-President and Chief Actuary, which position he held when he retired in 1941

He was elected an associate of the Actuarial Society of America in 1900 and became a Fellow by examination in 1903. The other American actuarial body-the American Institute of Actuaries which combined with the Actuarial Society in 1949 to form the Society of Actuaries-was founded in 1909 and Hunter was elected a member in 1916. He was also a founder member of the Casualty Actuarial Society of America. He wrote the first text book on Disability Benefits for the Actuarial Society and collaborated in a revised edition which is still in use. He was President of the Actuarial Society in $1916 / 17$, having previously served as Secretary and as a Vice-President.

In 1896 the New York Life had begun to insure sub-standard lives, while in 1903 the Actuarial Society published the results of a Specialised Mortality Investigation but this covered only a few impairments and was very limited in its scope. Hunter subsequently published several papers giving the experience of his office on various types of risk and that experience was used by offices as a guide until a broader based medico-actuarial experience became available. That was provided by the Medico-Actuarial Mortality Investigation of 1912, carried out jointly by the Association of Life Insurance Offices' medical directors and the Actuarial Society. Hunter served on the 
Joint Committee and was Chairman of the Central Bureau in charge of the investigation.

He submitted a large number of papers to the actuarial bodies, many in collaboration with Dr Rogers, the Chief Medical Director of the New York Life, with whom he devised the system of Numerical Rating of life assurance risks.

Hunter maintained his interest in and kept in touch with the Faculty and readily gave information about the Medico-Actuarial Investigation when the Faculty and Institute, just before the first World War, were considering a joint venture in mortality investigation. More about this can be found in Davidson's admirable account of the origins and first 100 years of the Faculty published at the time of the Centenary. [The Faculty of Actuaries in Scotland, 1856-1956, p. 80.]

In the first World War Hunter was Chief Consulting Actuary of the U.S. Government and Chairman of the Advisory Committee of the War Risk Insurance Bureau there and was commended by the Secretary of the U.S. Treasury for his services. In 1939 the rank of Chevalier of the Legion of Honour was conferred on him by President Lebrun and in 1946 he received from King George $\mathrm{V}$ a medal for "services in the cause of freedom " which was a treasured possession.

Hunter was what Davidson describes as "the spearhead of the Scottish actuarial invasion of the U.S." He gained a distinguished place for himself in American actuarial circles and did much to enhance the reputation of the Faculty in America. He retained a close interest in and deep affection for his native Scotland to which he paid frequent visits and, by an arrangement he had made some years before his death, his remains were interred in the Stevenson family burial ground in Melrose Abbey Churchyard, the plot being that of his forebears on his mother's side. On a visit shortly after the first World War he addressed the Faculty on "Current topics in the U.S." and afterwards spoke to a number of young actuaries about the bright prospects in the U.S.A. for the right men. It was at that time the writer first met him. The impression left was of a small bright-eyed man exceptionally alert and active and one who had been so much influenced by his environment that, to the untutored ear, there seemed nothing in his accent or mode of speech that differed from that of the well established New York born professional man.

Among his numerous honours Hunter had conferred upon him in 1927 by Edinburgh University an honorary degree of LL.D. and he received a similar honour from Hamilton College, New York. He was also elected a Fellow of the Royal Society of Edinburgh. 
Hunter, a Scot born and educated in Edinburgh, never forgot his debt to his old school and to the Faculty. Shortly after he arrived in the U.S.A. three Watsonians, of whom he was one, "met in Philadelphia and formed what was probably the first branch of the Watsonian Club outside Edinburgh" [The Watsonian, 1955, Part I, p. 6]. About 1955 he "crowned a long record of munificence to the school by providing a scholarship for a Watson's boy to study for a year in an American residential college" (loc. cit). The scheme has been continued since then and has been administered by the EnglishSpeaking Union of New York and in 1959 Hunter "endowed the scholarship by making a substantial gift which, with contributions from members of the Watsonian Club in the U.S.A., will continue it for many years " [The Watsonian, 1958, p. 66, etc.]. This is clear and tangible evidence of his desire that young Americans and young Scots should get to know one another as intimately as possible in order to understand one another's points of view. He was a firm believer in the aims of the English-Speaking Union and the scholarship was one of the many practical ways in which he gave his support.

Hunter's interests outside the actuarial field were many and it is not surprising that an actuary who had been so closely associated with the medical profession should, after his retirement, take an active part in a non-profit insurance organisation providing hospital and medical and surgical benefits-the Blue Cross/Blue Shield Plan in New York of which he was an unpaid director-see J.I.A. vol. 95 p. 87.

In Montclair where he lived for more than 50 years he gave much support to religious, social and cultural activities. He was a Trustee of the Unitarian Church there and served as President for a period. He was also a Trustee of the Montclair Art Museum and served for two periods as President. A formal resolution by the Trustees refers to " devoted interest and generosity ... shown by your many gifts throughout the years for which you were named a benefactor in 1952." He was also for a time a Trustee and had been President of the Mountainside Hospital.

As one would expect of a Scot, he was a member of the St. Andrew's Society and the Burns Society of New York and he had been President of both. Until the time of his death, he was Chairman of the Standing Committee of the former.

He was a keen golfer and did much to stimulate interest in the game both in Philadelphia where he first went and subsequently in Montclair where he lived for so long. He continued to play until a 
few years before his death, more, as he said, for the companionship and exercise than in any hope of improving his game.

Naturally, actuaries in this country know much less than they would wish about Hunter's brilliant career and many outside interests, so the writer has perforce based much of this memoir primarily upon an obituary notice prepared for the Society of Actuaries in the U.S.A. which has generously been made available to him, and on further information so readily and kindly supplied by the President of that Society, A. C. Webster, himself a Scot and a Fellow of the Faculty, and by Hunter's nephew, Arthur R. Hunter, once a student of the Faculty and now a senior partner in a firm of London stockbrokers. All the help received is most gratefully acknowledged. If the memoir gives a fair picture of the illustrious Arthur Hunter, the writer will feel that he has got as near to achieving his object as is possible in the circumstances.

He was a widower and is survived by two daughters, one unmarried, and the other, married and settled in California, has two children both married, and five grandchildren. Hunter was immensely proud of his grandchildren and of the distinction of having five great-grandchildren.

Finally, one can say without any fear of contradiction, that Dr. Arthur Hunter was a member of whom the Faculty will feel justly proud and one who did so much in his long life to add lustre to the name of the Faculty in North America.

R. Ll. G. 